\title{
CAREER GUIDANCE AND SOCIAL INCLUSION: A CHALLENGE FOR EUROPE
}

\author{
RONALD G. SULTANA
}

University of Malta

\begin{abstract}
This paper discusses the way career guidance is conceived across Europe as a policy instrument that can facilitate social inclusion. It locates current articulations of career guidance within the broader social-market aspirations of the European Union, providing an account of several reviews and analyses of the field that have been carried out at both member state and regional levels. The paper examines how the prevailing model of lifelong career guidance in Europe ties into strongly embedded notions of social welfare that, while increasingly challenged by neoliberal imperatives, nevertheless continue to strive to ensure solidarity towards all citizens, especially those most at risk of social exclusion. Within such an articulation, career guidance in Europe is keen not only to facilitate autonomy and self-sufficiency by equipping citizens with the life skills needed to manage educational and occupational pathways, but also to provide the support required throughout life, when and where it is needed. However, while much has been done in Europe to cater for the career guidance needs of vulnerable groups, it is clear that several challenges remain.
\end{abstract}

\section{INTRODUCTION}

Over the past decade, career guidance has attracted an unprecedented amount of policy attention in Europe, leading to several initiatives at both national and cross-national levels. While there is a long history of European Union (EU) policy involvement in the field of career guidance (see Watts, Sultana \& McCarthy, in press), the review of guidance services by the Organisation for Economic Co-operation and Development (OECD), launched in 2000 and finalised four years later (OECD, 2004), served as a trigger for the intensification of policy 'busyness' both in highand middle-income countries. Several single-country studies were carried out, leading to comparative regional analyses of the state of career guidance across the European Union and European Economic Area countries (Sultana, 2003, 2004, 2008; Sultana \& Watts, 2006). Similar studies, using much the same research methodology, were also carried out in the Balkans (Sweet, 2006), in other EU neighbouring countries (Zelloth, 2009), and in the Middle East and North Africa (Sultana \& Watts, 2007). Another study focused on developing countries associated with World Bank projects (Watts \& Fretwell, 2004). The reviews focused on guidance services in both the education and the labour market sectors, and considered guidance not only as a way to meet labour market goals — such as improving the match between the demand and supply 
of skills—but also as a policy tool to help attain social equity and inclusion goals for both young people and adults. In Europe, such an approach ties into strongly embedded notions of social welfare which, while increasingly challenged by neo-liberal imperatives, nevertheless continue to strive to ensure solidarity for all citizens, especially those most at risk of social exclusion. Career guidance as it is currently conceived in Europe is thus keen not only to facilitate autonomy and self-sufficiency by equipping citizens with the life skills needed to manage educational and occupational pathways but also to provide the support required throughout life, when and where needed.

The various reviews of career guidance in Europe show that most countries value career guidance as a public service that is freely available inside and outside schools. There is an appreciation of the fact that guidance helps to identify and re-motivate underachieving students, can significantly lower drop-out rates and can cater for those at risk of disengaging by supporting their move back into education and training, thus improving their chances of labour market integration. Similarly, in the labour market sector, funding of European public employment services (PES) is often justified in relation to the principle of solidarity for marginalised groups and the disadvantaged. Such groups include young people who leave school without any qualifications, and who are not in education, employment or training, as well as the long-term unemployed. Some countries have developed services targeting other vulnerable groups, such as those who risk losing their jobs due to the restructuring of the enterprise they work for (e.g., Austria, France, Germany, Portugal, Spain, the United Kingdom), women returners (e.g., Cyprus, Czech Republic, Greece, Malta, Spain), those living in remote areas (e.g., Cyprus, Hungary, Poland, Spain), the disabled (e.g., Flemish-speaking Belgium, Bulgaria, Cyprus, Estonia, Hungary, Iceland, Lithuania, Norway, Romania, Spain), ethnic minorities, immigrants and asylum seekers (e.g., Flemish-speaking Belgium, Finland, Germany, Greece, Iceland, the Netherlands, Norway, Sweden), gypsies (e.g., Czech Republic, Romania), prisoners and ex-offenders (e.g., Denmark, Ireland, Lithuania), drug abusers (e.g., Finland), and ex-servicemen (e.g., Denmark, Germany, Greece, Lithuania).

Indeed, in several countries in Europe, such is the focus on those who are 'at risk' that there is some concern that 'mainstream' groups are not being adequately catered for. Service gaps have thus been noted in relation to young people and adults who are neither job seekers nor students, to employed workers needing information and advice in relation to job mobility and to older workers. The next sections will consider some of the targeted services offered to vulnerable categories of European citizens within both the education sector and the labour market.

\section{Guidance Provision for 'A T-RISK' AND 'OUT-OF-SCHOOL' YOUTH}

While some form of guidance service is, in many countries across Europe, generally available to students across the board, there is also targeted provision for those who are considered to be 'at risk'. These typically include those who leave school early without any qualifications and who thus find themselves constantly on the brink between unemployment and unskilled, low-paid work, if not petty criminal activity. While several education ministries across Europe have striven to cater for such students-many, for instance, have set up 'second chance' schools-guidance services have not been particularly successful in developing effective strategies to respond to the needs of such young people. This may be partly due to the fact that guidance services tend to be associated by such youths with the very system they resist or have abandoned-which is why such innovative strategies as the use of ex-school drop-outs as peer counsellors (e.g., in Flemishspeaking Belgium) are promising.

The various country studies and reviews suggest that the aim of reintegrating such young people within education or training programs as quickly as possible is also more likely to be attained if the service is offered outside the school but in collaboration with it, either by public employment services or by community associations with which young people are more likely to identify and feel at home. Public employment services in several European countries (e.g. France, Germany, Italy, Luxembourg, Malta, Norway, Portugal, Romania, Sweden) have tended to adopt a broadly similar approach based on early intervention. At-risk youth are offered a range of individualised approaches where personal, educational and occupational guidance are woven together, and where pre-vocational programs-including courses in basic literacy, in self-confidence building, and in job 
seeking-support the insertion of clients into training and eventually into jobs. Often, young people are encouraged to take responsibility for their own futures by drawing up an individual action plan, and in many cases are invited to work through this with a guidance officer as part of a mutual obligation arrangement. Such early intervention is mandatory in some countries (e.g., Denmark, Italy, Sweden), where the relevant municipal authorities are required by law to make contact with, and offer guidance to, young people who have dropped out of school and lack any formal qualifications. In the best of cases, public employment services as well as community associations work hand in hand with guidance staff from schools in order to ensure that resources are pooled in the interests of young people 'at risk', with a view to increasing social inclusion and reducing the numbers of those who are in neither education, employment nor training. Many of these projects are supported by the European Social Fund.

\section{Guidance Provision for the UNEMPLOYED}

Unemployed adults are the main recipients of career guidance across Europe. Often, the providers are public employment services (PES). While European PES offices share much the same goals and methodologies of similar services worldwide, those in EU member and accession states have adopted common policies in dealing with unemployment, in relation to the targets and priorities established by the European Employment Strategy and the European Employment Guidelines. Such concerted strategy building is facilitated by the Network of European Public Employment Services. The latter promotes guidance as an effective tool for assisting job seekers, and has carried out studies exploring good practice across Europe (Expert Group, 2002). Increasingly the aim has been to 'activate' clients, with PES staff helping the unemployed develop a personal action plan. European countries target a whole range of unemployed persons who are considered to need special support, including the long-term unemployed, women returnees, persons with disabilities, ethnic minorities, young people with no formal qualifications and work experience and (less often) asylum seekers and ex-offenders.

The overall framework driving PES in Europe highlights the role that guidance can play in routing clients through training and into jobs. This reflects a cultural change underway in many PES towards a more supportive and facilitative role, with the service becoming a gateway to guidance rather than a gatekeeper. But recent Europe-wide surveys (Sultana, 2004; Sultana \& Watts, 2006) suggest that this guidance role is still often underdeveloped, and subordinated to other tasks which tend to take precedence in the broad remit of responsibilities that PES staff have to shoulder. Thus, several European countries, and particularly those that have only recently joined the EU, report that their PES focus tends to be on training for employability, on information giving and on job brokerage. Staff are also involved in channelling the unemployed towards training and retraining tracks, and in many cases they administer income support schemes for clients. As a consequence, the guidance function often ends up being muted, particularly since PES staff are typically overburdened with multiple roles (e.g., Cyprus, Czech Republic, Denmark, Germany, Latvia, Malta, the Netherlands, Slovakia), and since the criterion for evaluation of provision tends to be the rate of successful job placements of clients. This further skews services towards brokerage and networking with potential employers.

While some countries are keeping the roles and tasks of PES staff integrated (e.g., Denmark, France, Iceland, Norway, Spain), others are reforming their services in such a way that different categories of unemployed people are better served by specialised provision. One of the options that exists for public employment offices that have not separated out the different roles and functions is to organise their service in tiered levels. This can help them to cope with the diverse needs of clients and to free time and resources for guidance (e.g., Austria, Finland, Germany, the Netherlands, Portugal, the United Kingdom). There are typically three levels or tiers of service. At the first level, PES users have access to information in a selfservice mode, through the use of dedicated materials or online. A second tier of service provides groupbased help, which can include job clubs, sessions that help clients recover self-confidence and motivation, or that teach them basic literacy skills, how to write curriculum vitae, how to sit for interviews and a range of other employability skills. A third tier of service provides personal guidance to those who are perceived to need it or who feel they can benefit from it. The management of the service in this way not only contributes to more efficient use of resources through 
screening but also enables some role differentiation, with semi- or para-professional categories catering for basic information and advice needs, while others with more professional training in guidance provide the third-tier services, aimed largely at the most 'at-risk' clients.

Unemployed adults may have access to career information and guidance in settings other than those provided by the PES. Most often, community-based organisations provide services to specific groups, especially if the groups are the targets of national equity policies. Some European countries (e.g., Belgium, Luxembourg, Portugal, Spain, Sweden) have reported an increasing number of projects that community-based associations have organised on their own (either as selffinanced initiatives, or more often through outsourcing by the PES), or in collaboration with a public agency (e.g., Luxembourg's Femmes en Détresse project, which works with victims of marital violence, and the Adult Educational Guidance Initiative in Ireland, which targets unemployed adults who wish to take up education and training). Typically, such initiatives cater for unemployed adults who suffer from social or physical disadvantages: the community-based organisations that work with them are considered to be closer to the realities of these target groups, and therefore potentially more effective in responding to their needs. Citizens might also feel more comfortable with such forms of provision, which tend to be built around personal rather than bureaucratic service cultures (Bezanson \& Kellett, 2001).

Adults, whether unemployed or in part-time employment, can also access career guidance services if they are enrolled in higher education institutions or in other forms of adult education and training. Here, some institutions have developed guidance services targeting special groups of students, including women who are hoping to return to the labour market after a period of time out for child rearing. Increasingly falling within the remit of guidance services are 'second-chance' schemes, which try to facilitate the entry of undereducated but highly motivated adults into further and higher education and training tracks through the accreditation of prior and experiential learning. Some countries have taken this kind of strategy on board at a national level-England, for instance, has established regional adult, information, advice and guidance partnerships with the intention of encouraging poorly qualified and low-skilled adults to return to education. France, Norway, Portugal, Flemish-speaking Belgium and Greece have also made strides towards the development of systems of assessment of prior learning, or bilan des compétences.

\section{Conclusion}

A recently published study commissioned by the EU agency Cedefop (Sultana, 2008) which examined progress attained in implementing targets for career guidance agreed to by the Council of Ministers of Education in 2004, suggests that much is being done across the $\mathrm{EU}$ to enhance access to career guidance, particularly for those most in need. Country update reports that provided the data for the review suggest that several EU member states are attempting to reach out to disadvantaged youths through a range of innovative strategieswhich include mentoring schemes (Denmark), and specially designed workshops that engage young people on their own terms (Finland) —outside formal institutions that tend to be associated with negative experiences. Many have intensified their attempts to target early school-leavers, developing school guidance programs to detect and assist young people who leave school early or without qualifications to help them to find meaning in staying at school, and to have well-planned exit strategies to enable them to re-engage in learning and successfully complete their secondary education (Greece, France). Some countries are attempting to work more closely and across sectors with other individuals and agencies (PES staff, youth workers, social workers, community workers and other adults) who might be better placed to reach out to disaffected youth, to ensure the latter develop the necessary competences to manage career and learning during post-compulsory school years in second-chance learning programs, employment training programs and so on. Increasingly, too, personal action planning strategies are being implemented, encouraging students to develop a 'personal development plan' (Belgium-Flanders, Denmark) or an 'individual education plan' (Ireland), thus aiming to put into place preventive measures rather than merely 'curative' ones. 
Several countries have also expanded or reinforced access to guidance to groups of adults who have traditionally had lesser opportunities to benefit from specialised services, including immigrants (Poland, Finland), travellers (Ireland, Romania), offenders (the United Kingdom) and people with disabilities (Malta, the Netherlands, Poland, Spain, Sweden). Some of the best practice across Europe and beyond involves vulnerable groups in designing, planning, implementing and monitoring career guidance policies and services, thus greatly improving development of services relevant to their needs.

It is worth noting that several of the approaches being implemented across Europe may very well be underpinned by a deficit approach to the 'at-risk', since they tend to assume that the failure to be integrated in training routes and in the labour market is caused principally, if not wholly, by citizens' lack of specific attributes. There are other, potentially more empowering approaches to the issue of 'social exclusion'. These focus on the demand rather than the supply side of the equation, and therefore on education, training and economic and labour market deficits (Reid, 2008; Soto, 2005). These approaches are thus, for instance, more apt to critique inflexible school systems that fail to be responsive to the differentiated needs of students from diverse social, economic, cultural and ethnic backgrounds. Particularly in times of economic crises, when employment opportunities are increasingly hard to come by, and when governments are tempted to 'export' the blame away from the economy onto citizens themselves, a critique of deficit approaches becomes even more essential.

Furthermore, recent country reports suggest that there are important lacunae in the provision of guidance services. Few reports mentioned any specific initiatives targeting senior citizens. This is an important gap, given that ageing populations and demographic structures are leading to pension funding problems across most of Europe, a state of affairs that will require both later retirement ages and more flexible transitions to retirement. Citizens need specialised information and advice to support active ageing: part-time work, more fulfilling leisure, voluntary work and activities to keep them mentally and physically fit. Most adult guidance providers have been slow to mobilise career guidance services to support such active ageing. Flexible transitions between full-time work and full-time retirement (mixing full-time work, part-time work, voluntary work and periods of inactivity) will require much closer harmonisation of career and financial planning. Employers and worker representatives can promote and take initiatives in service delivery of thirdage guidance, using combinations of public and private partnerships.

Despite several efforts to reach out to the community and to plug gaps in service provision in an effort to make guidance more universal, reports about guidance from countries across Europe suggest the prevalence of what can be referred to as the 'Mattheus effect'. There is a tendency for those who most need the service to be the least likely to receive it, either because they are not aware of its benefits or because the way the services are conceived, packaged and delivered fails to connect with where particular groups of clients are at in a geographical or social sense. There are also concerns that career guidance, as a 'language', speaks exclusively or mainly to particular groups of clients, identifiable by their location in the social structure. This important challenge can perhaps best be overcome if users are engaged to shape services, thus avoiding the propensity for professionals to mould services in their own image. While much has been done in Europe to cater for the guidance needs of vulnerable groups, it is clear that several challenges remain.

\section{REFERENCES}

Bezanson, L., \& Kellett, R. (2001). Integrating career information and guidance services at a local level. Paper prepared for the OECD Career Guidance Policy Review.

Expert Group (Personalised Services with Special Focus on Guidance and Counselling). (2002). PES role in guidance and counselling: An insight into current thinking and practices. Report of a group chaired by G. De Man. Brussels: VDAB. Retrieved 13 January 2010 from http://libserver.cedefop. eu.int/vetelib/eu/pub/cedefop/internal/2004_0003_en.pdf

Organisation for Economic Co-operation and Development. (2004). Career guidance and public policy: Bridging the GAP. Paris: Author. 
Reid, H. L. (2008). Career guidance for at risk young people: Constructing a way forward. In J. A. Athanasou \& R. Van Esbroeck (Eds.), International handbook of career guidance (pp. 461-485). Netherlands: Springer.

Soto, N. M. (2005). Working with youth at risk of exclusion. In B. A. Irving \& B. Malik (Eds.), Critical reflections on career education and guidance: Promoting social justice within a global economy (pp. 143-157). Oxon, UK: RoutledgeFalmer.

Sultana, R. G. (2003). Career guidance policies in 11 acceding and candidate countries. Turin: European Training Foundation.

Sultana, R. G. (2004). Guidance policies in the learning society:

Trends, challenges and responses across Europe. Thessaloniki: Cedefop.

Sultana, R. G. (2008). From policy to practice: A systemic change to lifelong guidance in Europe. Thessaloniki: Cedefop.

Sultana, R. G., \& Watts, A. G. (2006). Career guidance in Europe's public employment services: Trends and challenges. Brussels: DG Employment, Social Affairs and Equal Opportunities.
Sultana, R. G., \& Watts, A. G. (2007). Career guidance in the Mediterranean. Turin: European Training Foundation.

Sweet, R. (2006). Career guidance in the Western Balkans region. Mimeo. Turin: European Training Foundation.

Watts, A. G., \& Fretwell, D. H. (2004). Public policies for career development: Policy strategies for designing career information and guidance systems in middle-income and transition economies. Washington, DC: World Bank.

Watts, A. G., \& Sultana, R. G. (2004). Career guidance policies in 37 countries: Contrasts and common themes. International Journal for Educational and Vocational Guidance, 4, 105-122.

Watts, A. G., Sultana, R. G., \& McCarthy, J. (in press). The involvement of the European Union in career guidance policy and practice: A brief history. International Journal for Educational and Vocational Guidance.

Zelloth, H. (2009). In demand: Career guidance in EU neighbouring countries. Turin: European Training Foundation.

Ronald G. Sultana can be contacted at <ronald.sultana@um.edu.mt>. 